UDC 82.0

DOI: $10.24045 / f v .2017 .1 .5$

\title{
BYRONIC HERO, LITTLE MAN OR SUPERFLUOUS MAN
}

\author{
L. Khanjani \\ H. Fallah Binakar
}

\author{
Ph.D., assistant professor \\ student \\ University of Guilan, Rasht, Iran
}

\begin{abstract}
Byronic hero, in English literature, and little man and superfluous man, in Russian literature, which respectively, have been developed by George Gordon Byron and Alexander Pushkin, later, has become a symbol or a criterion to writers and poets. They are heroes with unique characteristics, which have led to extensive development in the style of writing and storytelling. This paper is trying to study the characteristics of Byronic hero, Little man, and the Superfluous man, and after examining them, remarkable literary works and their origin, find that if lord Byron's Byronic hero, in English literature is the same "little man" of Russian literature or its "superfluous man"; and in general, what is the effect(s) of Byronism on Russian literature and development of its heroes.
\end{abstract}

Keywords: Hero; Literature; Byronic Hero; Little Man; Superfluous Man.

Russian literature, which currently has a special status and position in the world of literature, compared to English and Europe literature, has had a relatively late initiation. While the world of literature was changing in other countries due to introducing different literary styles, in Russia, feudalism and the hierarchy of nobility still dominated on education and learning. Learning and literacy belonged just to a particular group, and in addition, since Russia claimed that is an independent and self-sufficient country and don't require communication with other nations, translation was also forbidden, therefore reading literary works among the upper classes was possible only through original language. This is why Russian literature, before the permission of Peter the Great to translation in the 18th century and familiarization with the literature of other countries, was a backward country in the field of literature, and why Russian literature in 19th-century is as the world's literature in classical period, i.e., the centuries 15-16. But, little by little, as a results of great revolutionary developments in the late 18th and early 19th centuries, which includes a series of industrial, economic and social developments, as well as communicating with other countries, writing something other than history and some courtly plays, despite imposing severe government censorship, became popular, and fiction, poetry, novel, and totally literature flourished.

By initiation of writing fiction and novel, characterization and creating heroes in literary works, also become more coherent. It is worth pointing out that he culture of Russians, their lifestyle, and their ruling system, which may differ from other countries, have 
significantly affected Russian literary heroes, and the reaction of characters in fictions have been influenced by the period that writer lived in it. Most of Russian heroes in the 19th century are little man or superfluous man, however at the same time, in England, where romantic style was common, Lord Byron had created Byronic hero.

There are a few studies on comparing heroes in Russian literature and Byronic hero, as well as this question that whether Lord Byron's Byronic hero is the same little man in the stories of Pushkin and Gogol, or superfluous man of Pushkin and Turgenev; and this paper tries to achieve an appropriate answer to this question by studying characteristics of these heroes and their reaction toward events. To this end, initially, introduce these heroes.

Little man has an important position in Russian literature of 18-19th century and has attracted the attention of most writers; and since each of these writers have their own way to portray little man in their works, it has changed over years and this change is very important to understand the whole of Russian literature in the 20th century. The theme of the little man, in literature, is along with human traditions. Writers such as Pushkin, Gogol, Lermontov and Dostoyevsky have chosen this theme. This theme reflects the lives of ordinary people with all their experiences, problems and entertainment. Writer undertake difficult task of showing and describing the lives of ordinary people. Little man is representative of all people and each writer shows it in its own way.
Karamzin is the first writer who discovered the world of our little man. His greatest impact is due to "Bednaya Liza"(Poor Liza), the story of a country girl, who committed suicide after a tragic romantic relationship; this work of Karamzin has opened the way to future writers such as Pushkin, Gogol, Chekhov, and Dostoyevsky. However, in fact the most prominent writer of little man's world is Pushkin, who not only is contemporary of Lord Byron, but also in aspects of social class, physical appearance and somehow a defect in appearance, longevity, literary style, and many others things has similarities with him.

Pushkin and Gogol's heroes are the best representatives of Little Man. Pushkin looks his heroes from outside and does not separate them from society. Now the question is: who is Little Man of Pushkin's work, as creator of this type of character. Little Man, in fact, refer to a little social position, i.e. one of the lowest social hierarchy and human position that receive little attention, if any; because, his world and ideals are little and restricted, and along with a variety of obstacles and problems. He never attracts others' attention and has always been forgotten and humiliated. His life has small joys and his problems seem trivial and even does not seem worthy of attention. Little man lives unconsciously and completely as dead. But, they, sometimes, depending on the circumstances, and in compliance with the cry of their souls, try to fight against the authorities and stop injustice. This man is weak in dealing with life. Sometimes might protest, and always, as a result 
of this protest and rebellion, there will occur a critical event that result in death.

Theme of Little Man is prominent in Pushkin's verse tale of the Bronze Horseman, which is considered as one of the most influential works in Russian Literature. The main theme of this verse is conflict between the needs of government and the needs of ordinary citizens. Pushkin, in this poem, narrates the fate of Eugene and his beloved, Parasha, during the floods of the River Neva. Eugene, the hero of this work, after the death of Parasha, and in a fit of rage, curses the bronze statue of Peter the Great on the horseback, he is mad at Peter the Great for the founding Saint Petersburg in a bad weather area, and indirectly believes he is responsible of his beloved death. he is so mad that think the statues is alive and even the horseman pursuing him; the poem closes with the discovery of his corpse in a ruined hut floating on the water. In this work, a Little Man, Eugene, is fronted the government. He, even at the moment that is very angry, dares to threaten horseman. This is a Little Man, who rebelled against the government; as a result, there is no end to him except death.

There is a distinction between Eugene, the hero of Pushkin's the Bronze Horseman, and Eugene the hero of his Eugene Onegin. The Former is a Little Man but the latter is Superfluous Man, which apparently are not alike! This distinction refers to arrival of a new artistic movement of Romanticism to Russia. Romanticism that Byronism and George Byron's Byronic Hero are its prominent characteristic; perhaps, a brief review on this movement is useful to confirm that is there any distinction or not.

George Gordon Byron, who is known simply as Lord Byron is one of the greatest poets in the Romantic Movement at the late 18th and early 19th century. He experienced a lot of riot, despite his short life. He spent most of his time on dissoluteness and self-gratification. Romantic relationships that Lord Byron experienced in life, made him as true sample of Don Juan, one of his heroes; so that, eventually had to leave England forever. What have highlighted him among other writers were the characteristics of his heroes.

What has created Lord Byron - the great English poet-undoubtedly is one of the most important phenomena of literary history and social thoughts. His poetic works has embodied the most important aspects of his era. His poem was direct response to great revolutionary developments of the late 18th century and early 19th century, which is common theme of European Romanticism, as a specific path of spiritual life in that time that emerged as a reaction to the French Revolution and training [2, p. 378].

Prior to Byron, the dominant genre in the poetry was epic. Byron was first one who created new lyrical poetry, which later, in the 19th century expanded in literature world. 19th century, which is the era of dramatic social developments, and the period of collapsing Feudalism and emerging Capitalism, was along with bourgeois revolutions, which despite expectations were not associated with freedom and justice. Now, the thought of people 
had changed and despite the weakness of social development, they found that returning to the past time is not possible. In these difficult circumstances, a wave of new ideas and conflicting emotions which were trying to form a new world, led to creating artistic movement that called Romanticism.

It can be claimed that Byron, before being a poet has been as idol of his generation, not only in England, but also in all the Europe. His poems were read and immediately imitated. His works are one of significant phenomena in the history of world literature and social thought. The most important issues of his era have embodied in his works. Although he was committed to enlightenment ideals and classicism aesthetic, he is a romantic poet. Enlightenment ideas in his works are represented in a new form and without previous optimism and his main dream is human freedom.

One of the main reasons of distinctive influence of Byron, compare to his contemporary literary style was rooted in this fact that he protested more comprehensive against the position of boring bourgeoisie. Widespread despair of Revolution and global regret about freedom of the world, along with perceived imagination of human revolution lead to the abstractive nature of this protest. Byron became the master of torment and raiser of social conscience, and this is highly distinctive in the history of Byronism.

Byron, through his works which display the violence, historical and unusual situation drama, has found great influence and reputation in Europe. Goethe calls Byron "the greatest geni- us of our century". His trip to Europe resulted in writing two parts of his narrative poem, Childe Harold's Pilgrimage (1812). Although this poem is a comedy - epic work about the adventures of a young man, who travels to Europe, at the same time, is a sharp satire against London society at that time. This poem includes elements that make it as Byron's life, because he has written this work based on some experiences from his trips between 1809 and 1811. Of course he rejects any form of relationship and similarity between Harold and himself.

Childe Harold is the first romantic hero of Byron's poems; a character that has no similarity with literature's traditional heroes; a character with vague spiritual desires and dissatisfaction with the world and wisdom. The hero that is called Byronic Hero has strong ideals and motivation on particular issue, however, in general, has characteristically a lot of weakness, and sometimes commits actions that socially are abominated. Perhaps, some of his behaviors and actions are unethical, and perhaps, as much as he does good deeds, does bad ones, but does not aim to satisfy his wickedness and evil nature. Byronic hero is often male, and has physical attractiveness, complexity, and high intelligence, and emotionally is very sensitive, so that make him an extremely erratic person. This hero is often extremely introspective, and may be described as a bitter and thoughtful person; he often is pessimistic and tired due to his mysterious, bothersome and dark past; has strong personal beliefs, beliefs that generally are in conflict with the val- 
ues, conditions and norms of society. He thinks his values and concerns are more important than the values and concerns of anyone else. He, frequent$1 y$, is involved in a romantic relationship, which usually does not have a happy end and often leads to a duel. Harold, the hero of Childe Harold's Pilgrimage, was dedicated his life just to leisure and pleasure and felt loneliness in the world. He is low-spirited and tired, despite of having a famous and noble family and a life full of leisure and pleasure, and perhaps mentally is ill. He decides to find a new world, so leave his country, which has become as prison to him.

The impact of this work on writers and artists of the Romantic period and writers of Gothic style, in the 19th century is significant. The main characters of novels such as The Hunchback of Notre-Dame, The Count of Monte Cristo, Wuthering Heights, Jane Eyre, and other English literary works, are somehow, Byronic Hero. Of course, these characters in the works of Dickens have changed to new mood.

Romanticism or perhaps Byronism also had a significant impact on development of Russian literature. The first encountering of Russians educated society with Byron's works has been in year of 1920s. During 1820 to 1826 , some of his poems were translated into Russian, and before that, the Russian intelligentsia were familiar with some of his works in the original language. Byron's creativity has stimulated Russian literature development, awakening the mind and ethical concerns. The impact of Byronic Hero has been revealed in characterization of Russian literature, which will discuss later. It should be noted that Russian literature heroes are known by names such as Little Man, Superfluous Man, and sometimes Wandering and Unknown man that latter ones are beyond the scope of our discussion.

Romanticism in Russia has perceived since Pushkin and Lermontov time. Relationship between studying Byron's creativity, not only along with the effect of its subsequent literature that includes Russian literature, but also with much of his work, according to new literary genres, is an innovation in various fields of poetry. Byron's years of living are fraught with events that have influenced history of the world. It is reasonable that assume Romanticism formed by French Revolution, the Great Patriotic War 1812, the character of Napoleon, and feelings of freedom in the global community.

The 19th century is along with unprecedented growth in all domains of social - artistic life. As Belinsky famous Russian critic-says separating country's culture is not possible, and it is natural that assume the literary community is not limited to a particular country and the way of learning, understanding and appreciating the creativity of other countries is open. And now the question is that, whether the works of Lord Byron influenced Russian literature or not? The answer definitely is No. Therefore, how much have been the impact of Lord Byron on Russian poets and writers?

Byron has inspired many followers of freedom idea. Information about Byron arrived Russia quickly and after publication of Childe Harold's Pilgrimage in French. Now that Byron 
had created a new language to express, all classic genres of poetry shattered, and Russian poet encountered a way, free from boring patterns of poetry; and there was a perfect and creative style to express thoughts, feelings and attitudes of man in 19th century.

Byron's works have had great influence on creation of some poems by Pushkin. Poems such as Poltava, The Prisoner of the Caucasus, and The Fountain of Bakhchisarai are some of them. Pushkin thought many of Byron's works and perhaps due to his influence emerged as a poet. The theme of freedom has considerable position in Pushkin's romantic poems. During years of exile in the South, i.e. the years of 1820 to 1824 , the influence of Romanticism and Byron has been very outstanding in his work. In these years, he became familiar with Byron and his work in French. Now, freedom, almost had become the main theme of his work, and it was due to disappointing from all previous ideals, and lack of believing their realization. Now love of freedom and wish of releasing from prison had become his romantic dream. For instance, in the Prisoner, he has compared himself with a free bird, a young eagle, who wish fly to far distance; eagle that is symbol of freedom in romantic poetry. He gradually, composed some other poems under influence of Byron.

Dominating conditions in Russia, during 19th century, and particularly during the period of Nicholas I, has led to formation of a new character type in Russian literature, which somehow was similar to Byronic Hero. The concept of Superfluous Man, for the first time, introduced between 1830s and 1840s, in Russian literature. This Character, for the first time, formed in Eugene Onegin, by Pushkin, between the years 1825-1832, matured in A Hero of Our Time, by Lermontov, and culminated in the Diary of a Superfluous Man by Turgenev.

Belinsky believes superfluous man is the yield of Nicholas I era and his reactionary sovereignty, in which, high educated members of the community were deprived from entering government system. They did not have another option to express their inner talents and therefore, adopted a passive life. David Paterson describes Superfluous Man, not merely other literary type, but also a pattern of a man who has lost a thing, a place, or a nature in the life, and finally, introduces him as forlorn man [1, p. 1-3]. Superfluous Man- an alone and outcast man that reveal a painful phenomenon of Russian society spiritual life- has arose from the crisis of social system. Superfluous Man who is known as Byronic Hero in the works of Lord Byron and according him is a person who has left alone in the world, has obvious moral advantage. Belinsky believes that this character mainly is man of word not action, and this is not his fault, instead the fate has surrounded him; he is a man who has no noble goal and thinks he should has, and believe nothing; As a result of selfishness, he doesn't even like himself, and everything is boring to him.

Superfluous Man is representative of a man with remarkable ability that belonged to the upper class, and cannot flourish his talents in the era of 
Nicholas I. He is belonged to a noble family; and abhors the bureaucracy. He often, makes busy himself by unimportant entertainment. His life style leads to duel, gambling and other destructive behaviors. He mentally is fatigue and full of doubts between words and action. This hero, not only gets into trouble, but also brings to misfortune female character of story, who loves her. In general, he is a controversial figure, which is in conflict with society; has disputed relationships with his parents, has failed in love, and has an unstable position in the society; and often is victims of a duel. Pushkin's Eugene Onegin is also an intelligent, highly educated hero that has suppressed others; he is charming and mysterious; attracts females irresistibly and is out of the society and the law.

Among Byron's works, Childe Harold Pilgrimage has great influence on creation of Pushkin's Eugene Onegin, the first work that can be considered as symbol of Superfluous Man in Russian literature. Eugene, Superfluous Man of this book, who inherits a landed estate from his uncle, to escape his everyday life, moves to the country, and there, becomes familiar with a beautiful girl, Tatyana. And although Tatyana becomes intensely drawn to him, he fall in love with Olga her sister and the fiancé of his friend, Vladimir Lensky, and this forbidden love leads to a duel, which during it, Onegin unwillingly kills Lensky, therefore quits his country. After that, Eugene Onegin became uninterested Olga. Tatyana also married and went Petersburg. Over the years, Eugene sees Tatyana along with her husband, and this time fall in love with the girl, whose love he had once turned away, and so on. It should be noted that, Pushkin has rejected Byron's influence, and as we can see, his Eugene Onegin reflects poetic independence of this Russian genius that is a reality resulted from a thinker brain [3, p. 6-8]. Remarkable point is that after death of Byron in 1824, both Romanticism and Byronism died to Pushkin, and he bid farewell the South and Romanticism by the end of his exile.

Mikhail Lermontov also, in "A Hero of Our Time", by introducing Pechorin as Superfluous Man to his contemporary society, matured this type of character. Lermontov has written this book during 1838-1840 that is considering as the first social - psychological novel in Russian literature, and all attention of the writer has paid on discovering the inner world of hero, dialectic of his soul, psychological analysis of his emotions and affections, and the history of humanity spirit; Pechorin, hero of this novel, is an intellectual aristocrat in the reign of Nicholas I, that is considered both product and victims of that period. He, either in terms of job or mental reactions is a warrior. Lermontov's Superfluous Man is more individualistic than Superfluous Man in works of Pushkin [3, p. 1-3]

Despite all similarities between characteristics of Superfluous Man in Russian literature and Byronic Hero of England, this type is somehow in contrast to Little Man. In theme of little man, there is an excuse to fate, and contrary, in Superfluous Man, categorized incentives are dominated, which may be related to revolt of hero or are resulted from him. Superfluous Man potentially is able to do anything; he 
has the confidence to change anything, but Little Man, due to the society that lives, is powerless, and not only is powerless to change anything, but also self-confidence is dead in him. Ac- cording to the texts and what have mentioned, comparing the characteristics of these three character types are presented in the following table:

\section{Characteristics of the Little Man, Byronic Hero, Superfluous Man}

\begin{tabular}{|c|c|c|}
\hline Little Man & Byronic Hero & Superfluous Man \\
\hline $\begin{array}{l}\text { Low social position } \\
\text { Alone, outcast of society } \\
\text { Forgotten, humiliated } \\
\text { Victims of bureaucracy and } \\
\text { government } \\
\text { Without extraordinary abilities } \\
\text { and talent } \\
\text { Small happiness } \\
\text { Small aspirations } \\
\text { Introspective } \\
\text { Unconscious life } \\
\text { Weak people } \\
\text { Without confidence } \\
\text { Inferiority complex } \\
\text { Harmless } \\
\text { Seemingly unimportant prob- } \\
\text { lems } \\
\text { Revolt resulted in death }\end{array}$ & $\begin{array}{l}\text { High social position, well edu- } \\
\text { cated, nobility } \\
\text { Alone, outcast of society } \\
\text { Controversial figure, in contrast } \\
\text { to custom } \\
\text { Abhors the bureaucracy } \\
\text { Karamzik and mysterious, } \\
\text { physical attractiveness } \\
\text { Worthless entertainment } \\
\text { Great ideals } \\
\text { Introspective } \\
\text { Unconscious life } \\
\text { Weakness of character } \\
\text { Superiority complex } \\
\text { High intelligence } \\
\text { Disputed relationships with } \\
\text { parents } \\
\text { Sensitive and moody } \\
\text { Pessimistic and mental fatigue } \\
\text { Romantic involvement with } \\
\text { unpleasant end } \\
\text { Coercion to leave the territory } \\
\text { Victim of duel }\end{array}$ & $\begin{array}{l}\text { High social position, well } \\
\text { educated, nobility } \\
\text { Alone, outcast of society } \\
\text { Controversial figure, in } \\
\text { contrast to custom } \\
\text { Abhors the bureaucracy } \\
\text { Karamzik and mysterious } \\
\text { Worthless entertainment } \\
\text { Great ideals } \\
\text { Introspective } \\
\text { Unconscious life } \\
\text { Many doubts between } \\
\text { words and action } \\
\text { Superiority complex } \\
\text { High intelligence } \\
\text { Disputed relationships } \\
\text { with parents } \\
\text { Gamble } \\
\text { Pessimistic and mental } \\
\text { fatigue } \\
\text { Romantic involvement } \\
\text { with unpleasant end } \\
\text { Coercion to leave the ter- } \\
\text { ritory } \\
\text { Victim of duel }\end{array}$ \\
\hline
\end{tabular}

\section{Conclusion}

Each writer, according to his/her interests and writing style creates a hero with special characteristics. little man, superfluous man and Byronic hero, three heroic types of 18th and 19th centuries, in Russian and English literature have their own features and characteristics that sometimes are sim- ilar and common. Both Pushkin, the creator of little man, who first time considered heroes from outside, and the first one who has created superfluous man influenced by Byron, and Byron, whose hero is a symbol of Western Romantic, have tried to make their hero more tangible to readers, by highlighting some characteristics in them. 
Weak and outcasts men of lower class - little Men - and apparently more confident and outcasts men of upper class - Superfluous Man, and Byronic Hero, despite all differences, have common characteristics. Apparently, there is no similarity between them, but, the origin of all is one. All have same fate, all are outcasts and sentenced to death; a death that is definitely not physical. Perhaps a death due to rebellion against the government, or a death as a result of poverty, and perhaps a death by duel. In fact, all three of these characters are weak. It seems that Byronic Hero and Superfluous Man are opposite to Little Man, and apparently are wealthy and powerful, but in fact have internal weakness. Perhaps Pechorin, superfluous man of "A Hero of Our Times", which is the first psychological novel of that era, is evidence to this word. Investigating changes of these three heroes in literature of Russia and England, and later literary, 20th and 21st centuries, and this fact that what is prominent characteristic of these heroes in contempo- rary period can be the subject of future study.

\section{Bibliography}

1. Доброзракова Г.; Алиханов и Печорин : автобиографический герой Сергея Довлатова - лишний человек Нового времени. 2011.

2. Жирмунский В. М. Избранные труды Байрон и Пушкин. Пушкин и западные литературы. - Л. : Издательство «Наука», 1978.

3. Калинин Н. Влияние Джорджа Байрона на русскую классическую литературу. 2016.

\section{Bibliography}

1. Dobrozrakova G.; Alihanov i Pechorin : avtobiograficheskij geroj Sergeja Dovlatova - lishnij chelovek Novogo vremeni. 2011.

2. Zhirmunskij V. M. Izbrannye trudy - Bajron i Pushkin. Pushkin i zapadnye literatury. - L. : Izdatel'stvo «Nauka», 1978.

3. Kalinin N. Vlijanie Dzhordzha Bajrona na russkuju klassicheskuju literaturu. 2016.

(C) Khanjani L., Fallah Binakar H., 2017. 